\title{
BİST'e Kayıtlı Bilişim ve Teknoloji Alanında Faaliyet Gösteren İşletmelerin Finansal Performanslarının Analitik Hiyerarşi Prosesi (AHP) ve Gri İlişkisel Analiz (GİA) Yöntemiyle Değerlendirilmesi
}

\author{
Nezih TAYYAR * \\ Fatma AKCANLI ** \\ Erhan GENÇ ${ }^{* * * * * *}$ \\ Iş1l EREM
}

\section{ÖZET}

Bu çalışmada Borsa İstanbul'a kayıtlı bilişim ve teknoloji sektöründe faaliyet gösteren işletmelerin finansal performanslarının değerlendirilmesi amaçlanmıştır. Bu bağlamda söz konusu sektörde faaliyet gösteren ișletmelerin 2005-2011 yılları arasındaki finansal tablo verileri kullanılarak oran analizi gerçekleştirilmiştir. Öncelikle Analitik Hiyerarşsi Prosesi yöntemi kullanılarak ă̆ırlı̆̆ en fazla olan kriter elde edilmeye çalışılmuş, daha sonra Gri İlişkisel Analiz yöntemi uygulanarak sektördeki işletmelerin performanslarına yönelik her bir işletme için ele alınan yıllar itibariyle gri ilişkisel dereceler hesaplanmıştır. Çalışmanın sonucunda ağırlı̆̆ en fazla olan kriterin karlılık oranları olduğu sonucu elde edilmiş ve sektörde rakiplerine göre en yüksek finansal performansa sahip işletmenin Link Bilgisayar Sistemleri Yazılımı ve Donanımı Sanayi ve Ticaret A.Ş. olduğ görülmüsstür.

Anahtar Kelimeler: Analitik Hiyerarşi Prosesi, Gri İlişkisel Analiz, Teknoloji Sektörü, İstanbul Menkul Kıymetler Borsası.

JEL Siniflandirmast: D70, L25, L86.

Financial Performance Evaluation Of Technology Companies Quoted In BIST With Analytic Hierarchy Process (AHP) And Grey Relational Analysis (GRA)

\section{ABSTRACT}

The aim of this study is to evaluate the financial performance of the listed companies operating in information technology sector in Borsa Istanbul. In this context, the financial ratio analysis of these companies is made by using the financial statements between the years of 2005-2011 and the obtained data have been evaluated with Analytic Hierarchy Analysis and Grey Relational Analysis. Firstly, the weightiest criteria has been determined by using Analytic Hierarchic Process, then the grey relational degrees have been calculated for each company operating in the information technology sector in order to measure the financial performance. As a result of the study; it has been seen that the profitability ratios are the weightiest criteria and Link Bilgisayar Sistemleri Yazılımı ve Donanımı Sanayi ve Ticaret A.Ş. has the highest financial performance among the other companies operating in the same sector.

Keywords: Analytic Hierarchy Process, Grey Relational Analysis, Technology Sector, Borsa Istanbul.

Jel Classification: D70, L25, L86.

\footnotetext{
*Yrd.Doç.Dr. Nezih Tayyar, Uşak Üniversitesi, İ.İ.B.F, nezih.tayyar@usak.edu.tr

** Yrd.Doç.Dr. Fatma Akcanlı, Uşak Üniversitesi, İ.İ.B.F., fatma.akcanli@usak.edu.tr

**** Arş.Gör. Erhan Genç, Uşak Üniversitesi, İ.İ.B.F., erhan.genc@ usak.edu.tr Arş.Gör. Işıl Erem, Uşak Üniversitesi, İ.İ.B.F., isil.erem@usak.edu.tr
} 


\section{GíRiş̧}

Geçmişten bugüne hızlı bir şekilde değişim ve gelişim sürecinin yaşanması, 80’li yıllardan bu yana makro açıdan ülke ekonomilerinde, mikro açıdan ise işletme yapılarında daha fazla hissedilmektedir. Dünya ekonomisinde meydana gelen finansal gelişim ve ilerleyen teknoloji küresel alanda artan bir rekabet ortamını getirmiştir. Bu rekabet ortamı da işletmeleri dışa açılmaya, yenilik yapmaya ve teknolojide meydana gelen gelişmelere ayak uydurmaya zorlamaktadır (Akın, 2005: 3).

Dünyada meydana gelen değişimin temel nedenlerini bilim, iletişim, bilgisayar ve ulaşım teknolojilerinde meydana gelen hızlı gelişmeler oluşturmaktadır. Geçmişten bugüne bilginin oluşturulması, depolanması, düzenlenmesi, kullanıma hazır hale getirilmesi, iletilmesi, kişilerin hizmetine sunulması ve kullanılması yönünde fark edilebilir boyutlarda değişimler meydana getirmiştir. Bilgide meydana gelen değişimleri sağlayan teknolojiler, bilişim teknolojileri olarak adlandırılmaktadır (DPT, 2001: 1).

Toplumların ve ülkelerin kalkınmasında bilişim sektörünün önemi her geçen gün daha da artmaktadır (Aydın, 2012: 180). Bilgi çağı olarak adlandırılan bu çağda dünya ekonomisine yön verenler; güvenilir ve eksiksiz bilgiyi elinde tutan, bilgiyi en iyi şekilde yönetebilen ve pazarlayabilen ülkeler olarak kabul edilmektedir (Önder, 2008: 162).

Bilişim teknolojileri işletmelere bilginin sağlanması ve kullanımı konusunda fayda sağlamakta olup, işletmelere daha sağlıklı stratejik kararlar alma yönünde de yol gösterici bir rol oynamıştır. Ayrıca bilişim teknolojileri işletmelerin maliyetlerini düşürücü ve performanslarını arttırıcı yönde de avantajlar sağlamaktadır.

Bilginin bu şekilde kullanılması ancak bilişim teknolojilerinin üretilmesi ve kullanılması ile gerçekleşebilmektedir. Bu bağlamda ülkelerin ekonomilerinde bilişim ve teknoloji sektörüne daha fazla önem vermeleri ve bu sektörü çeşitli şekillerde desteklemeleri gerekmektedir. Ülke ekonomilerinde büyük öneme sahip olan bilişim sektörünün durumu, bilişim sektöründe faaliyet gösteren işletmelerin performansları ile yakından ilişkilidir.

Ekonomik faaliyetlerin çok hızlı bir şekilde devam ettiği günümüzde teknoloji, ulaşım ve haberleşme alanındaki gelişmeler işletmelere küreselleşmenin etkilerini her geçen gün biraz daha fazla hissettirmektedir (Cengiz ve Çağlar, 2011: 129). İşletmelerin şiddetli ve zorlu rekabet koşulları altında başarıyı yakalayabilmeleri, yeni pazarlarda kendilerine yer bulabilmeleri ve süreklilik sağlayabilmeleri, bugün ve gelecekteki faaliyetleri karlı olarak sürdürebilmeleri işletme performanslarının doğru olarak tespit edilip değerlendirilmesi ile ilgilidir (Tekin ve Zerenler, 2005: 187).

İşletmelerin performanslarının değerlendirilmesi ve analiz edilmesi; işletme eksiklerinin daha rahat bir şekilde görülmesi, performansı olumsuz olarak etkileyen faktörlerin belirlenmesi, geleceğe yönelik hedeflere zamanında ve daha verimli bir şekilde ulaşılmasında işletme yöneticilerine büyük faydalar sağlamaktadır. Performans değerlemesi 
ile işletmeler, varlık ile kaynakların ölçümünü ve değerlendirilmesini gerçekleştirerek, bu varlık ve kaynakların geliştirilmesini sağlamaktadırlar (Bayyurt, 2007: 578).

Bilgi teknolojileri ve iletişim sektörü günümüzde en önemli endüstri kollarından birini oluştururken (Kulalı ve Bilir, 2010: 5), sektörün diğer endüstri kollarının verimliliğini arttırıcı ve kolaylaştırıcı bir yönü bulunmaktadır. Ayrıca Türkiye ekonomisi açısından bu sektörde meydana gelen 1 birimlik büyümenin ekonominin genelinde 1,8 birimlik bir büyüme etkisi yapacağı düşünülmektedir (YASED, 2012: 3). Bununla birlikte DPT (2007) raporuna göre de, bilgi ve iletişim teknolojileri sektörü, dünya genelinde meydana gelen değişim ve gelişim sürecinde çok büyük stratejik öneme sahip olan sektörlerden birisi olarak nitelendirilmektedir (DPT, 2007: 5). Bu bağlamda ülke ekonomisi üzerinde önemli bir role sahip olan bilişim ve teknoloji sektörünün performansının ülke ekonomisine de önemli oranda katma değer sağladığı ifade edilebilir. Bu nedenle bilişim ve teknoloji sektörünün performansının ortaya konması büyük önem taşımakta ve bu çalışmanın konusunu oluşturmaktadır. Çalışmada, İMKB'de bilişim ve teknoloji alanında faaliyet gösteren işletmelerin 2005-2011 yılları arasındaki finansal verileri oran analizi yöntemiyle değerlendirmeye alınmış ve belirlenen oranlar, Analitik Hiyerarşi Prosesi ve Gri İlişkisel Analiz yöntemleri kullanılarak söz konusu işletmelerin performansları değerlendirilmiştir.

\section{LITERATÜR TARAMASI}

Analitik Hiyerarşik Prosesi (AHP) ve Gri İlişkisel Analiz (GİA) yöntemleri, finansal performansı değerlemede kullanılan yöntemlerdendir. Literatürde üretim, pazarlama, mühendislik ve finans gibi çeşitli alanlarda söz konusu yöntemler ile yapılmış çalışmalara rastlamak mümkündür:

Lee, Kwak ve Han (1995) çalışmalarında, finansal ve finansal olmayan performans ölçütlerini kombine etmek ve performans değerlemede içsel faktörlerin yanı sıra dışsal faktörlerin de oldukça önemli olduğunu vurgulamak amacıyla üç aşamalı bir hiyerarşik plan hazırlamışlardır. Diğer performans değerlendirme yöntemlerine göre AHP yönteminin; yapısal esneklik, geri bildirim kolaylığı, grup değerlendirme kapasitesi, duyarlılık analizi, hesaplama kolaylığı gibi birçok avantajlı yönünün söz konusu olduğu görülmüştür. Çalışmanın sonucunda ayrıca, AHP yönteminin finansal performans değerlemede stratejik kontrolün yanı sıra operasyonel kontrole de yardımcı olduğu belirtilmiştir

Rangone (1996) çalışmasında; belli bir işletme içindeki çok sayıda departmanın performansını finansal ve finansal olmayan veriler ışı̆̆ında değerlendirmeye almak ve bu departmanlar arasında performans karşılaştırması gerçekleştirmek amacıyla AHP modelini uygulamıştır. Çalışmada ağırlıklı olarak AHP modelinin varsayımlarına, getirdiği sınırlamalara ve performans ölçüm veya karşılaştırmada modelin nasıl kullanılması gerektiğine odaklanılmıştır. Sonuç olarak, AHP modelinin bölüm yöneticilerine ürün/ hizmet geliştirmede öncelik vermesi gereken unsurlar, etkin kaynak tahsisinin nasıl 
gerçekleştirileceği ve yapılması gereken teknolojik yatırımlar konusunda yol gösterici bir model olduğu kanısına varmıştır.

Barbarasoğlu ve Pinhas (1995) çalışmalarında; sermaye kısıtlaması kararına ilişkin olarak AHP yönteminden yararlanmışlardır. Çalışmada İstanbul $\mathrm{Su}$ ve Kanalizasyon İdaresi'ne Dünya Bankası tarafından verilen 650 milyon dolarlık bir kredinin, su dağıtımı projeleri arasında nasıl bir tahsisatı yapılacağı hususunda çeşitli proje seçim yöntemleri denenmiş ve tüm niceliksel ve niceliksel olmayan faktörleri tek bir modelde analiz etmek amacıyla AHP yöntemini ele almışlardır. Yöntem kullanılırken; ekonomik gelişmeler, projenin ekonomik ve politik açıdan kabul edilebilirliği, çevresel faktörler ve çeşitli risk unsurları da dikkate alınmıştır. Çalışmanın sonucunda ise yönetime sunulan proje çözüm önerisi uygun görülmüştür.

İç ve Yurdakul (2001) çalışmalarında, bankalar için bir kredi değerlendirme modeli geliştirerek, mali inceleme, subjektif kredi değerliliği, faaliyet gösterilen sektörün özellikleri ve kredi teminatı kriterleriyle AHP yöntemini uygulamışlardır. Çalışmalarının sonucunda, belirlenen kriterlerin sektörlere göre ağırlıklandırılmasını, hesaplanan mali oranların 0-1 arası bir puanla puanlandırılma aralıklarının belirlenmesini ve bütün bunların konusunda uzman kişiler tarafından yapılması gerekliliğini vurgulamışlardır.

Yüksel ve Akın (2006) çalışmalarında; bir tekstil işletmesinin başarısı üzerinde etkili bulunan stratejik faktörleri ve söz konusu faktörlerin izlenmesindeki stratejileri fursatlar, üstünlükler, tehditler ve zayıflıklar olarak belirlemiştir. Belirledikleri faktörleri ve stratejileri matrise dönüştürerek, bu matris modelini AHP yöntemiyle çözmüşlerdir. Çalışmalarının sonucunda; belirledikleri faktörler arasında en yüksek ağırlığı, profesyonel yönetim kadrosu oluşturmakta olup, daha sonra marka ve piyasadaki güvenirlik olarak tespit etmişlerdir. İşletmenin izleyeceği öncelikli stratejiyi “yurt dışı tedarikçilerle ortaklık yapmak” olarak açıklamışlardır.

Kung ve Wen (2007) işletmelerin finansal performanslarını değerlendirmede Gri İlişkisel Analiz yönteminin uygun bir yöntem olduğunu ifade etmiş ve Tayvan' daki yirmi tane girişim sermayesi şirketlerinin finansal performanslarını 2001-2003 yılları arasında söz konusu yöntem aracılığıyla belirleyerek belli bir sıralamaya tabi tutmuştur. Bu noktada Tayvan'daki girişim sermayesi şirketlerinin finansal performansları için en fazla önem arz eden finansal oranları ve bu şirketlerin finansal performansını en fazla etkileyen diğer finansal performans göstergeleri belirlemek adına yirmi tane finansal oranı sınıflandıran altı finansal göstergeden yararlanılmıştır. Analiz sonuçları; yirmi finansal orandan beş tanesinin (Faaliyet karı/Aktif toplamı, Vergi öncesi kar/Aktif toplamı, Faaliyet gelirleri/Aktif toplamı, Faaliyet gelirleri/Net defter değeri, Faaliyet gelirleri/Uzun vadeli yatırım oranı) ele alınan şirketlerin finansal performansları üzerinde etkili olduğunu göstermiştir.

Özdemir ve Deste (2009) çalışmalarında, otomotiv sektöründe faaliyet göstermekte olan bir işletmenin seksen iki tedarikçisi için yapılan performans değerlendirmesini, çoklu 
alternatifler arasında karşılaştırma yaparak GİA yöntemini uygulamışlardır. Çalışmalarının sonucunda seksen iki tedarikçi içinde mevcut değerlendirme yöntemiyle en iyi tedarikçiyi belirlemişlerdir. Ancak mevcut değerlendirme yönteminin, farklı ölçeklere sahip kriterlerin değerlendirilmesindeki eksikliklerden dolayı en iyi tedarikçi haricindeki diğer sıralamalar için farklı sonuçlar ortaya çıkabileceğini belirtmişlerdir.

Karğın (2010) hisseleri borsada işlem gören ve tekstil sektöründe faaliyet gösteren firmaların finansal performanslarını ölçmeyi ve karşılaştırmayı amaçladığı çalışmasında AHP ve TOPSIS yöntemlerinden yararlanmıştır. Yapılan çalışmanın sonucunda; firmaların finansal performanslarını belirlemede karlılık ve likidite oranlarının ilk iki sırada yer aldığı görülmüştür. Daha sonra ise sırayı piyasa performansını değerlendiren oranlar, faaliyet oranları ve finansal yapı oranlarının takip ettiği sonucu elde edilmiştir.

Cheng- Ru Wu, Chin- Tsai Lin ve Pei- Hsuan Tsai (2010) çalışmalarında; Tayvan'daki varlık yönetimi bankalanı için belli bir performans değerleme çerçevesi oluşturmada AHP ve GİA yöntemlerinden yararlanmışlardır. Çalışmalarında dikkate alınması gereken en önemli performans göstergelerini; kapasite karlılığı, müşteri karlılık profili, belli bir müşteri grubu için operasyonel kalite ve varlık yöneticilerinin profesyonel bilgisi olarak belirlemişlerdir.

Peker ve Baki (2011) çalışmalarında Gri İlişkisel Analiz yöntemiyle sigorta sektöründe faaliyet gösteren üç şirketi finansal performanslarına göre sıralamayı amaçlamıştır. Likidite, kaldıraç ve karlılık oranlarının dikkate alındığı çalışmanın sonucunda likidite oranları yüksek olan işletmenin daha yüksek finansal performansa sahip olabileceği sonucuna ulaşılmıştır.

Arifin (2011) çalışmasında; optimal bir portföyün iyi bir performans gösteren ve aralarında pozitif korelasyon olmayan hisse senetlerinden oluşması gerektiği, dolayısıyla herhangi bir portföyün tek bir sektörden oluşturulmaması gerektiğini vurgulamıştır. Ayrıca çalışmada, finansal oranlar kriteri ile kombine olmuş AHP yönteminin, Endonezya kömür madenciliği sektöründe işlem gören hisse senedi sıralamasında uygun bir yöntem olup olmadığının belirlenmesi amaçlanmıştır. Kullanılan finansal oranlar; cari oran, asit- test oranı, faaliyet karı oranı, borç/ öz kaynak oranı, yatırımın karlılığı, fiyat/ kazanç oranı, piyasa değeri/defter değeri olmak üzere yedi adet orandan oluşmaktadır. Çalışmanın sonucunda ise; AHP yönteminin finansal oranların tutarlılık göstermemesi sebebiyle söz konusu hisse senetlerinin performansını değerlemede yetersiz kaldığı görülmüştür.

Shu- Ling Lin ve Shun- Jyh Wu (2011) çalışmalarında; bankacılık sektörünün kredi risklerini analiz etmede GİA yönteminden yararlanmışlardır. Bankacılık sektörü için bir finansal kriz uyarı sistemi oluşturmada GİA yaklaşımı geliştirilmiş ve 111 örnekten oluşan bir veri seti üzerinde bir uygulama yapılmışlardır. Çalışmalarının sonucunda; GİA yönteminin lojistik regresyon, geriye yayılımlı sinir ağları gibi klasik yöntemlere göre daha doğru bir tahminleme gerçekleştirdiği kanısına varmışlardır. 
Hamzaçebi ve Pekkaya (2011) çalışmalarında; hisse senedi seçiminin yatırımcılar için oldukça önem taşıdığını ve hisse senedi seçimi yaparken bir takım finansal oranlardan yararlanabileceğini ifade etmişlerdir. Bu doğrultuda İMKB'ye kayıtlı olan 10'u banka, 5'i sigorta işletmesi ve 3'ü diğer finansal işletme olan toplam 18 işletmenin hisse senetleri veri seti olarak ele alınmıştır. Kriterlerin doğru bir şekilde ağırlıklandırılmasında üç yöntemden (AHP, LEvSA ve Buluşsal Senaryolar) yararlanılmış ve LEvSA' nın en uygun yöntem olduğu sonucu elde edilmiştir. Daha sonra GİA yöntemi uygulanarak hisse senedi seçiminde finansal oranların kullanımının finans sektöründeki işletmelerin hisse senetlerinin seçiminde de uygun olduğu sonucuna varılmıştır.

Perçin ve Karakaya (2012) çalışmalarında; likidite, faaliyet, karlılık, finansal kaldıraç ve piyasa değeri olmak üzere beş ana gruptan oluşan finansal oranlar yardımıyla bilişim teknolojisi firmalarının performanslarını belirlemeyi amaçlamış ve elde edilen performans sonuçlarıyla firmaların değerlerini karşılaştırmıştır. Bu bağlamda; söz konusu kriterlerin ağırlıkları Bulanık AHP yöntemi ile belirlenmiş, daha sonra ise TOPSIS yöntemi ile ele alınan firmaların finansal performans dereceleri hesaplanmıştır. Son olarak finansal performans dereceleri ile firma değeri arasındaki ilişkiyi tespit etmek adına gerçekleştirilen korelasyon analizi neticesinde ise; iki kavram arasında güçlü ve anlamlı bir ilişki olduğu görülmüştür.

Türkmen ve Çağıl (2012); çalışmalarında hisseleri borsada işlem gören ve bilişim sektöründe faaliyet gösteren on iki firmanın finansal performansları TOPSIS yöntemi yardımıyla tek bir puana çevirmeyi amaçlamış ve hesaplanan puanlar ile ele alınan firmaların performanslarının sıralamasını gerçekleştirmiştir.

\section{AMAÇ, KAPSAM VE VERÍLER}

Performans değerlemelerinin yapıldığı yerli ve yabancı literatürde yapılan çalışmalar genel olarak değerlendirildiğinde, ilgili çalışmaların genelinde AHP ve TOPSIS yöntemlerinin kullanıldığı görülmektedir. Bu bağlamda yapılan çalışmada, AHP ve GİA yöntemleri bir arada kullanılarak çalışmaya farklılık katılmaya çalışılmış ve diğer çok kriterli karar verme yöntemlerine göre daha sağlıklı ve tutarlı sonuçlar elde edilmiştir. GİA yönteminin değişkenlere sabit değerler verilerek analiz yapılabilmesine olanak sağlamasından dolayı çalışmadaki mali yapı oranlarına literatürde genel kabul görmüş ideal değerler verilerek analiz gerçekleştirilmiştir. Yapılan diğer çalışmalarda ise bu oranların sadece maksimum ve minimum değerler olarak ele alınmış olması yapılan çalışmaya bu anlamda da farklı bir boyut kazandırmıştır. Ayrıca yapılan çalışmanın uygulandığı sektör ve dönem itibari ile de yapılan diğer çalışmalardan farklılık gösterdiğini ifade etmek mümkündür.

Yapılan çalışmada BİST'e kote olan bilişim ve teknoloji sektöründe faaliyet gösteren 11 işletmenin verilerine eksiksiz bir şekilde 2005-2011 yılları aralığında ulaşılabilmesi sebebiyle, belirtilen dönem içerisinde söz konusu işletmelerin finansal performanslarının ölçümlenmesi amaçlanmıştır. Analize dâhil edilen işletmelerin belirtilen dönem aralığında 
ulaşılabilmesi nedeniyle İşletmelerin finansal performanslarının ölçülmesinde öncelikle oran analizi yöntemi uygulanmış olup, daha sonrasında AHP ve GİA yöntemleri kullanılmıştır.

Çalışmada kullanılan oranlar, literatürde işletme performanslarını ortaya koyan çalışmalarda kullanılan oranlarla benzerlik göstermektedir.

Günümüzde işletmelerin likidite ve borçlanma durumları ile faaliyetlerindeki verimlilik ve karlılık işletmelerin finansal performansları açısından büyük öneme sahip olmuştur. Bu bağlamda çalışmada işletme performanslarını ortaya koyarken likidite, mali yapı, karlılık ve faaliyet oranlarından en sık kullanılanları ele alınmış olup, Tablo 1, 2, 3, 4'de bu oranların neler olduğu ve nasıl elde edildikleri gösterilmiş, daha sonra ise söz konusu oranlara ilişkin açıklamalar yapılmıştır (Okka, 2011: 44-54).

Tablo 1: Likidite Oranları

\begin{tabular}{|l|l|l|} 
Kod & Değişken & Açıklama \\
\hline LO1 & Cari Oran & Dönen varlıklar/Kısa Vadeli Borçlar \\
\hline LO2 & Asit-Test Oranı & Dönen varlıklar-Stoklar/Kısa Vadeli Borçlar \\
\hline LO3 & Nakit Oranı & Hazır değerler/Kısa Vadeli Borçlar \\
\hline
\end{tabular}

Tablo 2: Mali Yapı Oranları

\begin{tabular}{|l|l|l|} 
Kod & Değişken & \multicolumn{2}{|l|}{ Açıklama } \\
\hline MYO1 & Borç Oranı & Toplam borçlar/Toplam Aktifler \\
\hline MYO2 & Toplam Borçlar/Özsermaye Oranı & Toplam Borçlar/Özsermaye \\
\hline MYO3 & Kısa Vadeli Yabancı Kaynakların Aktifi Karşılama Oranı & $\begin{array}{l}\text { Kısa Vadeli Yabancı Kaynaklar/Toplam } \\
\text { Aktifler }\end{array}$ \\
\hline
\end{tabular}

Tablo 3: Faaliyet Oranları

\begin{tabular}{|l|l|ll|}
\hline Kod & Değişken & Yçıllık Net Satışlar/ Ortalama Ticari Alacaklar & \\
\hline FO1 & Alacakların Devir Hızı Oranı & Net Satışlar/Özsermaye & \\
\hline FO2 & Özsermaye Devir Hızı Oranı & $\begin{array}{l}\text { Net Satışlar/(Dönen Varlıklar-Kısa Vadeli Yabancı } \\
\text { Kaynaklar) }\end{array}$ & \\
\hline FO3 & Net Çalışma Sermayesi Devir Hızı Oran & Yab \\
\hline
\end{tabular}

Tablo 4: Karlılık Oranları

\begin{tabular}{|l|l|l|} 
Kod & Değişken & Açıklama \\
\hline KO1 & Net Kar Marjı & Net kar/Net Satışlar \\
\hline KO2 & Aktif (Yatırım) Karlılık Oranı & Net kar/Toplam Varlıklar \\
\hline KO3 & Özsermaye Karlılık Oranı & Net kar/Özsermaye \\
\hline
\end{tabular}

\subsection{Likidite Oranları}

Likidite oranları, işletmelerin kısa vadeli borçlarını karşılayabilme durumlarını ölçen oranlardır (Erdoğan, 2011: 7). 
- $\quad$ Cari Oran (LO1): Bu oran dönen varlıkların kısa vadeli borçlara oranlanması ile elde edilen bir oran olup, işletmenin kısa vadeli borçlarını ödeme gücünün genel olarak ifade edilmiş bir şeklidir.

- $\quad$ Asit-Test Oranı (LO2): Dönen varlıklardan stoklar çıkarıldıktan sonra kısa vadeli yabancı kaynaklara oranlanması ile elde edilen bir oran olup, cari orana göre ödeme gücünün daha sağlıklı bir şekilde ölçülmesini sağlayan orandır.

- $\quad$ Nakit Oranı (LO3): Bu oran işletmenin hazır değerlerinin kısa vadeli borçları karşılama gücünü göstermektedir. Bu oran diğer likidite oranlarına yardımcı olmak amacıyla hesaplanır (Okka, 2011: 46).

\subsection{Mali Yapı Oranları}

Mali yapı oranları işletmenin hangi ölçüde borçla finanse edildiğini gösterir.

- Borç Oranı (MYO1): Bu oran aktiflerin hangi oranda borçlarla finanse edildiğini gösterir ve en yaygın kullanılan orandır. Toplam borçlara, kısa vadeli ve uzun vadeli borçların tümü dâhildir. İşletmenin borç oranı yükseldikçe finansal riskinin arttı̆̆ı kabul edilir. Bu oranın sektör ortalamasından yüksek olmaması tavsiye edilir. Borç oranının kreditörler tarafından düşük olarak istenmesinin nedeni; olası bir likidite sıkıntısında kaybı en aza indirmek düşüncesidir (Brigham ve Houston, 1996: 67).

- Toplam Borçlar/Özsermaye oranı (MYO2): İşletmeye ortakların ve kreditörlerin ne oranda sermaye katkısında bulunduğunu gösterir. Bu orana işletmenin finansal kaldıraç derecesi de denir (Okka, 2011: 51).

- $\quad$ Kısa Vadeli Yabancı Kaynakların Aktifi Karșılama Oranı (MYO3): İşletmede kısa vadeli borçların durumunu ve işletmenin finansal yapısı içerisindeki ağırlığını gösterir. Oranın yüksekliği; işletmenin borçlarının ödenme vadelerinin yakın olduğunu, ödeme riskinin yüksekliğini ve ödeme için finansal politikalar oluşturması gerektiğini ifade eder.

\subsection{Faaliyet Oranları}

- $\quad$ Alacakların Devir Hızı Oranı (FO1): Kredili satışların ortalama alacaklara bölünmesiyle elde edilmektedir. Alacakların ne kadar sürede nakde çevrilebildiğini gösteren orandır (Erdoğan, 2011: 9).

- $\quad$ Özsermaye Devir Hızı Oranı (FO2): Bu oran, öz sermayenin verimli kullanılıp kullanılmadığını gösterir. Oranın büyük olması işletmenin öz sermayesini etkin kullandığını veya öz sermayenin az olduğunu, finansmanda yabancı kaynaklardan geniş ölçüde yararlandığını gösterir (Usta, 2008: 121).

- $\quad$ Net Çalıssma Sermayesi Devir Hızı Oranı (FO3): Bu oran net satışların, dönen varlıkların kısa vadeli yabancı kaynaklardan farkına oranlanmasıyla elde edilmektedir. $\mathrm{Bu}$ oranın yüksek olması olumlu bir durum olarak değerlendirilse de elde edilen oranın rakip 
işletmelerin net işletme sermayesi devir hızları ile karşılaştırılması daha sağlıklı sonuçlar vermektedir (Okka, 2011: 49).

\subsection{Karlılık Oranları}

İşletmenin faaliyet döneminde kar sağlama açısından etkinliğini gösterir. Karlılık oranları işletmenin faaliyet performansını, risk durumunu ve finansal kaldıracın etkilerini ortaya koyar. Karlılık oranları etkinliği, satışlara oranla ya da yapılan yatırıma göre ölçülebilir (Türko, 1999: 107):

- Net Kar Marjı Oranı (KO1): Vergi sonrası net karın net satışlara oranlanmasıyla elde edilir. Satışların her bir lirasının ne kadar kar sağladığının bir göstergesidir.

- $\quad$ Aktif (Yatırım) Karlılık Oranı (KO2): Vergi sonrası net karın toplam aktiflere oranlanmasıyla hesaplanmaktadır ve işletmedeki toplam yatırımlardan elde edilen verim derecesini göstermektedir.

- $\quad$ Özsermaye Karlılık Oranı (KO3): Vergi sonrası net karın öz sermayeye oranlanmasıyla elde edilmektedir. İşletmeye yatırım yapan pay sahiplerinin yatırımlarının verim oranını göstermektedir.

\section{YÖNTEM}

İşletme performansları değerlendirilirken kullanılan yöntemlerden birisi de çok kriterli karar verme yöntemleridir. Bu yöntemler birden fazla alternatif ve birden fazla kriter söz konusu olduğunda işletme performanslarının ölçülmesinde (işletmelerin, en başarılı olandan en az başarılı olana doğru sıralanmasında) olumlu sonuçlar vermiştir. Çok kriterli karar verme yöntemlerinden bazıları AHP, TOPSIS, ELECTRE, PROMETHE, VIKOR, SAW ve GİA olarak söylenebilir. Bu çalışmada AHP ve GİA yöntemleri birlikte kullanılmıştır. Kriter ağırlıklarının bulunması için AHP yönteminden yararlanılmış, buradan elde edilen kriter ağırlıkları GİA'da kullanılarak işletme performanslarının değerlendirilmesi GİA yöntemi ile yapılmıştır.

\subsection{Analitik Hiyerarşi Prosesi (AHP)}

Analitik Hiyerarşi Prosesi (AHP), Thomas H. Saaty tarafından 1977 yılında geliştirilmiş bir tekniktir. Bu teknik pek çok alanda çok kriterli karar problemlerinin modellenmesinde başarıyla kullanılmıştır. AHP en genel tanımıyla kriterlerin ve alternatiflerin ağırlıklarının belirlenmesinde yapısal bir yaklaşım sağlar. Çok kriterli karar verme problemlerinin AHP ile modellenmesinde aşağıdaki aşamalar gerçekleştirilir (Ulucan (2007: 358):

- Problemin Tanımlanması,

- $\quad$ Kriterlerin Belirlenmesi, 
- Alternatiflerin ortaya konulması,

- Hiyerarşik ağaç diyagramının çizilmesi,

- Kriter Ağırlıklarının Belirlenmesi,

- $\quad$ Alternatiflerin her kritere göre puanlanması,

- Her alternatifin çok kriterli puanının elde edilmesi,

- $\quad$ Genel puanların karşılaştırılması ve en iyi alternatiflerin belirlenmesi.

AHP diğer çok kriterli karar verme yöntemlerinden farklı olarak kriterleri ikişerli olarak karşılaştırır ve karşılaştırmaların tutarlı olup olmadığını ölçer. Bu üstünlüğü nedeniyle AHP yalın olarak çok kriterli karar verme problemlerinin çözümünde kullanılmasının yanı sıra pek çok uygulamada ise kriter ağırlıklarının belirlenmesinde özellikle tercih edilmektedir. Kriter ağırlıkları AHP ile bulunduktan sonra bir başka çok kriterli karar verme yöntemi ile sıralamalar yapılabilir. Bu çalışmada da kriter ağırlıkları AHP ile belirlenmiş, ardından alternatiflerin sıralanmasında Gri İlişkisel Analiz yöntemi kullanılmıştır.

AHP ile kriter ağırlıklarının elde edilmesinde uygulanan adımlar aşağıda verilmiştir (Soner ve Önüt, 2006: 113-114):

Adım 1: İkili karşılaştırmaların yapılacağı karşılaştırma matrisi oluşturulur. Karşılaştırma yapılırken Saaty tarafından geliştirilen Tablo 5'de yer alan ölçek kullanılmaktadır.

Tablo 5: AHP Yönteminde Kullanılan Ölçek

\begin{tabular}{|c|c|l|}
\hline Önem derecesi & \multicolumn{1}{|c|}{ Tanım } & \multicolumn{1}{c|}{ Açılama } \\
\hline $\mathbf{1}$ & Eşit önemde & İki aktivite hedefe eşit olarak katkıda bulunur \\
\hline $\mathbf{3}$ & Biri ile diğeri kısmen aynı & $\begin{array}{l}\text { Tecrübe ve yargı ufak bir şekilde bir aktiviteyi } \\
\text { diğerinden daha çok favori tutar. }\end{array}$ \\
\hline $\mathbf{5}$ & Temel veya güçlü önem & $\begin{array}{l}\text { Tecrübe ve yargı güçlü bir şekilde bir aktiviteyi } \\
\text { diğerinden daha çok favori tutar. }\end{array}$ \\
\hline $\mathbf{7}$ & Çok güçlü veya ispatlanmış önem & $\begin{array}{l}\text { Bir aktivite diğerine göre çok güçlü tercih edilir ve } \\
\text { üstünlüğü pratikte ispatlanmıştır. }\end{array}$ \\
\hline $\mathbf{9}$ & Kesin önemlilik & $\begin{array}{l}\text { Bir aktiviteyi diğerine göre seçimin en yüksek şekilde } \\
\text { olduğu durumdur }\end{array}$ \\
\hline $\mathbf{2 , 4 , 6 , 8}$ & Komşu ölçü değerlerine bitişik ara değerler & Uzlaştırmaya ihtiyaç olunduğu zaman \\
\hline
\end{tabular}

Kaynak: Saaty (1980)'den aktaran Soner ve Önüt (2006).

Adım 2: Oluşturulan karşılaştırma matrisi standartlaştırılır. Bunun için sütun toplamları alınır ve her değer kendi sütun toplamına bölünür. Böylece standartlaştırılmış matris elde edilir.

Adım 3: Ağırlıkların elde edilmesi için satır ortalaması alınır. 
Adım 4: Ağırlıklar elde edildikten sonra karşılaştırma matrisinin tutarlığına bakılması gerekmektedir. Eğer karşılaştırma matrisi tutarlı değilse, elde edilen ağırlıklar kullanılamaz.

$$
A \cdot w=\lambda_{\max } \cdot w
$$

Eşitliğini sağlayan max vektörü öncelikle elde edilmelidir. Burada $A$ karşılaştırma matrisi, $w$ elde edilen ağırlık matrisidir. Eşitlik 2'de max kullanılarak hesaplamalar yapılır ve tutarlılığa yakınlık göstergesi olarak nitelendirilen "tutarlılık indeksi (CI)" elde edilir.

$$
C I=\frac{\lambda_{\max }-n}{n-1}
$$

CI değeri hesaplandıktan sonra, elde edilmesi gereken başka bir değer de "Rassallık İndeksi (RI)" dır. Bu değer farklı matris boyutları için çizelge haline getirilmiştir. Farklı matris boyutları için RI değerleri Tablo 6' da gösterilmiştir:

Tablo 6: Rassallık indeksleri

\begin{tabular}{|l|c|c|c|c|c|c|c|c|c|c|c|c|c|c|c|}
\hline $\mathbf{N}$ & 1 & 2 & 3 & 4 & 5 & 6 & 7 & 8 & 9 & 10 & 11 & 12 & 13 & 14 & 15 \\
\hline $\mathbf{R I}$ & 0.00 & 0.00 & 0.60 & 1.00 & 1.10 & 1.20 & 1.30 & 1.40 & 1.50 & 1.50 & 1.50 & 1.50 & 1.60 & 1.60 & 1.59 \\
\hline
\end{tabular}

Kaynak: Saaty (1980)'den aktaran Soner ve Önüt (2006).

Son olarak CI'nın RI'ya oranıyla "tutarlılık oranı (CR)" elde edilir. AHP uygulamalarında, CR'nin 0. 1' den daha az olması, yapılan uygulamanın tutarlı olduğunu gösterir. Eğer bu değer aşılırsa yapılan yargılar tekrar gözden geçirilmelidir.

\subsection{Gri İlişkisel Analiz (GİA)}

Gri Sistem Teorisi 1982 yılında Deng tarafından ortaya atılmıştır (Deng, 1989). Gri İlişkisel Analiz (GİA) Gri Sistem Teorisinin tekniklerinden birisidir. GİA her bir kriter ile kıyas yapılan referans serisi arasındaki ilişki derecesini belirlemeye yarayan bir yöntemdir (Üstünışık, 2007). Kriterler arası etki derecesi ise gri ilişkisel derece olarak isimlendirilir. GİA'nın diğer çok kriterli karar verme yöntemlerinden farkı referans seri kullanabilmesidir. Referans seride söz konusu kriterin aldığı en küçük ya da en büyük değerler kullanılabileceği gibi, duruma göre bunların dışında ideal değerler de kullanılabilir.

GİA genellikle altı adımda uygulanır (Zhai vd., 2009: 7074):

1. Adım: Karar Matrisinin Oluşturulması

Alternatiflerin her bir kriter için aldıkları değerleri gösteren karar matrisi oluşturulur, $\mathrm{n}$ alternatif, m kriterden oluşan karar matrisi, 


$$
X_{i j}=\left[\begin{array}{cccc}
x_{1}(1) & x_{1}(2) & \ldots & x_{1}(m) \\
x_{2}(1) & x_{2}(2) & \ldots & x_{2}(m) \\
\vdots & \vdots & \ddots & \vdots \\
x_{n}(1) & x_{n}(2) & \cdots & x_{n}(m)
\end{array}\right] \quad i=1, \ldots, n \quad j=1, \ldots, m
$$

Burada $x_{i}(j)$ i. alternatifin, j. kriter için aldığı değeri gösterir.

2. Adım: Standartlaştırma işlemi

Kriterler farklı birimlerle ölçüldüğünden dolayı, birbirleriyle karşılaştırılabilir hale getirmek için standartlaştırma işlemi yapılır. Standartlaştırma işleminde yüksek, düşük ya da ideal değerin tercih edilmesi durumuna göre üç farklı eşitlikten yararlanılır,

$$
\begin{aligned}
x_{i}^{\prime}(j) & =\frac{x_{i}(j)-\min _{i=1}^{n} x_{i}(j)}{\max _{i=1}^{n} x_{i}(j)-\min _{i=1}^{n} x_{i}(j)} \text { (büyük değer daha iyi ise) } \\
x_{i}^{\prime}(j) & =\frac{\max _{i=1}^{n} x_{i}(j)-x_{i}(j)}{\max _{i=1}^{n} x_{i}(j)-\min _{i=1}^{n} x_{i}(j)} \text { (küçük değer daha iyi ise) } \\
x_{i}^{\prime}(j) & =1-\frac{\left|x_{i}(j)-x_{i d l}(j)\right|}{\max \left\{\max _{i=1}^{n} x_{i}(j)-x_{i d l}(j), x_{i d l}(j)-\min _{i=1}^{n} x_{i}(j)\right\}} \text { (ideal değer daha iyi ise) }
\end{aligned}
$$

(6)

Burada $x_{i d l}(j)$ ideal değeri gösterir, standartlaştırma işlemi uygulandıktan sonra tüm durumlar için büyük değerler daha iyi duruma getirilmiş olur ve standartlaştırılmış değerler 0 ile 1 arasında değer alır.

3. Adım: Standartlaştırılmış karar matrisinin ve referans serisinin oluşturulması

$\mathrm{Bu}$ aşamada bir önceki adımda elde edilen değerlerden yararlanılarak standartlaştırılmış karar matrisi oluşturulur.

$$
X_{i j}^{\prime}=\left[\begin{array}{cccc}
x_{1}^{\prime}(1) & x_{1}^{\prime}(2) & \ldots & x_{1}^{\prime}(m) \\
x_{2}^{\prime}(1) & x_{2}^{\prime}(2) & \ldots & x_{2}^{\prime}(m) \\
\vdots & \vdots & \ddots & \vdots \\
x_{n}^{\prime}(1) & x_{n}^{\prime}(2) & \cdots & x_{n}^{\prime}(m)
\end{array}\right] \quad i=1, \ldots, n \quad j=1, \ldots, m
$$

Standartlaştırılmış karar matrisinin her sütunundaki en büyük değerlerden referans serisi oluşturulur:

$$
x_{0}^{\prime}=x_{0}^{\prime}(1), x_{0}^{\prime}(2), \ldots, x_{0}^{\prime}(m)
$$

4. Adım: Fark matrisinin oluşturulması

Standartlaştırılmış karar matrisinden referans serisi çıkartılarak fark matrisi elde edilir 


$$
\begin{aligned}
& \Delta_{0 i}(j)=\left|x_{0}^{\prime}(j)-x_{i}^{\prime}(j)\right| \\
& \Delta_{i j}=\left[\begin{array}{cccc}
\Delta_{01}(1) & \Delta_{01}(2) & \ldots & \Delta_{01}(m) \\
\Delta_{02}(1) & \Delta_{02}(2) & \ldots & \Delta_{02}(m) \\
\vdots & \vdots & \ddots & \vdots \\
\Delta_{0 n}(1) & \Delta_{0 n}(2) & \cdots & \Delta_{0 n}(m)
\end{array}\right] i=1, \ldots, n \quad j=1, \ldots, m
\end{aligned}
$$

5. Adım: Gri ilişkisel katsayıların hesaplanması

Fark matrisindeki her bir değer için gri ilişkisel katsayı hesaplanır,

$$
\gamma_{0 i}(j)=\frac{\min _{i=1}^{n} \min _{j=1}^{m} \Delta_{0 i}(j)+\zeta \times \max _{i=1}^{n} \max _{j=1}^{m} \Delta_{0 i}(j)}{\Delta_{0 i}(j)+\zeta \times \max _{i=1}^{n} \max _{j=1}^{m} \Delta_{0 i}(j)}
$$

Burada 0 ile 1 arasında değer alan bir katsayıdır ve genellikle 0.5 olarak alınır.

6. Adım: Gri ilişki derecesinin hesaplanması

Elden edilen gri ilişkisel katsayılar, ilgili kriterin ağırlığı ile çarpılıp, her bir alternatif için toplandığında gri ilişki derecesi elde edilir,

$$
\Gamma_{0 i}=\sum_{j=1}^{m} w(j) \gamma_{0 i}(j), \sum_{j=1}^{m} w(j)=1
$$

Burada $w(j)$, j. kriterin ağırlığını gösterir. Gri ilişki derecesinin her bir alternatif için aldığı değerler büyükten küçüğe doğru sıralandığında, alternatifler en iyiden en kötüye doğru sıralanmış olur.

\section{UYGULAMA}

Bu çalışmanın amacı İMKB'ye kayıtlı bilişim ve teknoloji alanında faaliyet gösteren on bir firmanın 2005-2011 yıllarını kapsayan performanslarını değerlendirmek ve firmaları en iyi performans gösterenden, en kötü performans gösterene doğru sıralamaktır. Çalışmada kullanılan hiyerarşik ağaç diyagramı Şekil 1'de verilmiştir. Şekilden de görülebileceği gibi 12 finansal oran (alt kriterler) "Likidite Oranları", "Mali Yapı Oranları", "Faaliyet Oranları" ve "Karlılık Oranları” başlıklarıyla dört ana kriteri oluşturmuştur. Her ana kritere ait üç alt kriter vardır. Uygulama yapılırken önce AHP yardımıyla kriter ağırlıkları bulunmuştur, ardından bulunan ağırlıklar GİA'da kullanılarak firmaların performansları en iyiden, en kötüye siralanmıştır. 
Şekil 1: Çalışmanın Hiyerarşik Ağaç Diyagramı

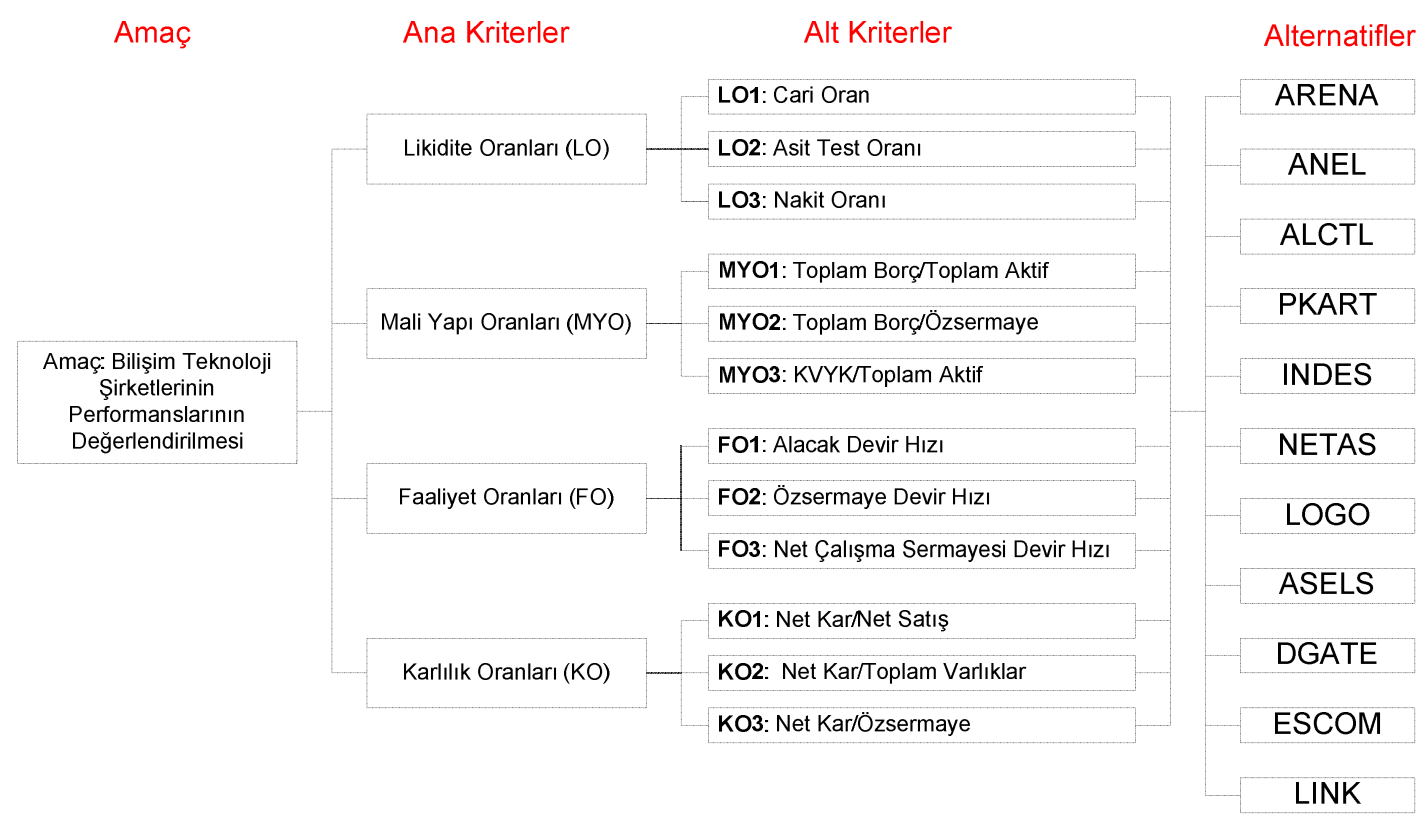

\subsection{AHP ile Kriter Ağırlıklarının Bulunması}

Kriter ağırlıklarının elde edilebilmesi için, alanında uzman olan altı kişi (akademisyen, banka müdürü, portföy yöneticisi) ana ve alt kriterleri anket yardımıyla ikişerli olarak karşılaştırmıştır. Bu karşılaştırmalarda Tablo 2'de verilen Saaty' nin geliştirdiği ölçekten yararlanılmıştır. Ankette önce dört ana kriteri birbirleriyle ikişerli olarak karşılaştıran 6 ifade yer almıştır. Ardından her ana kritere ait alt kriterler (oranlar) birbirleriyle ikişserli olarak karşılaştırılmıştır. Her ana kritere ait üç oran kullanıldığından, bunların ikişerli karşılaştırılması için üç ifade kullanılmıştır. Dolayısıyla ankette alt kriterlerin karşılaştırılmasında on iki ve ana kriterlerin karşılaştırılmasında 6 ifade olmak üzere, toplam on sekiz ifade yer almıştır.

Anketler değerlendirilmeye alınmış, ana ve alt kriterlerin tüm uzmanlar için tutarlılık oranları hesaplanmıştır. Yapılan hesaplamalarda bazı tutarlılık oranlarının 0.10'dan büyük olduğu görülmüştür. Bu durumda anketi yanıtlayan uzmandan anketin ilgili bölümündeki ifadeleri tekrar gözden geçirmesi istenmiş ve sonuçta tüm tutarlılık oranlarının 0.10' dan küçük olması sağlanmıştır. Çalışmada ana ve alt kriterler birden fazla kişi tarafından karşılaştırıldığı için, bunların değerlendirmelerini birleştirebilmek amacıyla ana ve alt kriterlerin geometrik ortalamaları alınarak Tablo 7'de verilen ağırlıklar elde edilmiştir. 
Tablo 7: Ana ve Alt Kriterlerin Ăgırlıkları

\begin{tabular}{|c|c|c|c|}
\hline Ana Kriterler & Alt Kriterler & $\begin{array}{l}\text { Alt Kriter } \\
\text { Ăğırlıkları }\end{array}$ & Ana Kriter Ağırlıkları \\
\hline \multirow{3}{*}{ Likidite Oranları (LO) } & LO1: Cari Oran & 0.097 & \multirow{3}{*}{0.185} \\
\hline & LO2: Asit Test & 0.326 & \\
\hline & LO3: Nakit Oran & 0.577 & \\
\hline \multirow{3}{*}{ Mali Yapı Oranları (MYO) } & MYO1: Toplam Borç / Toplam Aktif & 0.237 & \multirow{3}{*}{0.171} \\
\hline & MYO2: Toplam Borç / Özsermaye & 0.588 & \\
\hline & MYO3: KVYK / Toplam Aktif & 0.175 & \\
\hline \multirow{3}{*}{ Karlılık Oranları (KO) } & KO1: Net Kar / Net Satış & 0.609 & \multirow{3}{*}{0.456} \\
\hline & KO2: Net kar / Toplam Varlıklar & 0.135 & \\
\hline & KO3: Net kar/ Özsermaye & 0.256 & \\
\hline \multirow{3}{*}{ Faaliyet Oranları (FO) } & FO1: Alacak Devir Hızı & 0.390 & \multirow{3}{*}{0.188} \\
\hline & FO2: Özsermaye Devir Hızı & 0.144 & \\
\hline & FO3: Net Çalışma Sermayesi Devir Hızı & 0.466 & \\
\hline
\end{tabular}

Tablo 7'de görüldüğü gibi, ağırlığı en fazla olan ana kriter \% 45.6'lık oranla karlılık oranı birinci sırayı, \% 18.8'lik oranla faaliyet oranı ikinci sırayı, \% 18.5'lik oranla likidite oranı üçüncü sırayı ve \% 17.1'lik oranla mali yapı oranı da dördüncü sırayı almaktadır. Bir işletmenin ya da bir sektörün oran analizi yöntemiyle finansal yapısı değerlendirildiğinde, dönem net karın faaliyet karıdan yüksek çıkması söz konusu işletmenin ya da sektörün devamlı kar elde ettiği olarak yorumlanabilir.

\subsection{GİA İle İşletme Performanslarının Hesaplanması}

İşletmelerin performansları yıldan yıla farklılık gösterebilir, bu nedenle çalışmada ele alınan işletmelerin 2005-2011 yıllar arası performansları her yıl için ayrı ayrı değerlendirmek yerine, bu yılların aritmetik ortalamasını kullanmak, yıldan yıla oluşabilecek farklılıkları ortadan kaldıracak ve sektörün genel görünümünü verecektir.

GİA’nın uygulanmasında yukarıda verilen adımlar takip edilmiştir. Bu çalışmada11 alternatif (şirket), 4 ana ve 12 alt kriter vardır. 2005-2011 yılları ortalama oranlarından oluşan karar matrisi Tablo 8'de verilmiştir: 
Tablo 8: Bilişim ve Teknoloji Alanında Faaliyet Gösteren İşletmelerin 2005-2011 Y1lları Arası Finansal Oranlarının Ortalaması

\begin{tabular}{|l|c|c|c|c|c|c|c|c|c|c|c|c|}
\hline \multirow{2}{*}{ Şirket } & \multicolumn{3}{|c|}{ Likidite Oranları } & \multicolumn{2}{|c|}{ Mali Yapı Oranları } & \multicolumn{2}{c|}{ Karlık Oranları } & \multicolumn{3}{c|}{ Faaliyet Oranları } \\
\cline { 2 - 14 } & LO1 & LO2 & LO3 & MYO1 & MYO2 & MYO3 & KO1 & KO2 & KO3 & FO1 & FO2 & FO3 \\
\hline ALCTL & 1.32 & 1.19 & 0.19 & 0.79 & 4.20 & 0.71 & 0.01 & 0.02 & 0.09 & 2.76 & 7.30 & 7.15 \\
\hline ANELT & 2.43 & 2.26 & 1.34 & 0.52 & 2.55 & 0.33 & 0.00 & 0.00 & -0.09 & 3.51 & 1.52 & 5.96 \\
\hline ARENA & 1.38 & 0.89 & 0.08 & 0.71 & 2.72 & 0.70 & 0.02 & 0.06 & 0.22 & 8.05 & 14.72 & 16.46 \\
\hline ASELS & 2.58 & 1.51 & 0.67 & 0.68 & 2.18 & 0.24 & 0.15 & 0.05 & 0.17 & 6.88 & 1.36 & 1.11 \\
\hline DGATE & 1.38 & 1.02 & 0.09 & 0.74 & 3.44 & 0.73 & 0.01 & 0.03 & 0.17 & 8.54 & 16.56 & 17.07 \\
\hline ESCOM & 1.45 & 1.04 & 0.08 & 0.39 & 0.87 & 0.39 & 0.00 & 0.01 & 0.02 & 3.23 & 2.03 & -31.12 \\
\hline INDES & 1.30 & 0.93 & 0.06 & 0.75 & 3.03 & 0.72 & 0.01 & 0.03 & 0.14 & 5.51 & 10.99 & 12.92 \\
\hline LINK & 7.72 & 7.68 & 4.91 & 0.10 & 0.12 & 0.08 & 0.27 & 0.04 & 0.04 & 2.81 & 0.49 & 1.72 \\
\hline LOGO & 3.85 & 3.82 & 1.44 & 0.17 & 0.21 & 0.13 & 0.08 & 0.06 & 0.07 & 3.81 & 0.66 & 2.22 \\
\hline NETAS & 2.53 & 2.26 & 1.13 & 0.32 & 0.49 & 0.27 & 0.08 & 0.05 & 0.07 & 3.16 & 0.85 & 1.57 \\
\hline PKART & 17.91 & 13.33 & 10.01 & 0.13 & 0.16 & 0.05 & 0.00 & 0.02 & 0.02 & 10.14 & 1.33 & 1.96 \\
\hline
\end{tabular}

İkinci adımda standartlaştırma işlemi yapılmıştır. İlgili oranların işletmelerin bulunduğu sektöre, işletme büyüklüğüne, satışlarına ve işletmelerin uygulamış olduğu finansman politikasına göre farklılık gösterebiliyor olmasından dolayı normal koşullar altında oranların ideal değerlerini tam olarak söylemek mümkün değildir. Ancak çalışmada ideal değerler verilirken literatürde genel kabul görmüş oranlara yakın değerler ele alınmıştır. $\mathrm{Bu}$ bağlamda Likidite, Karlılık ve Faaliyet oranlarının yüksek değerler alması arzu edilir. Bu nedenle bu oranlar standartlaştırılırken Eşitlik 4 kullanılmıştır. Mali Yapı Oranlarının küçük ya da büyük değerleri yerine, kabul görmüş ideal değerleri vardır. Bu değerler Toplam Borç / Toplam Aktif ve Toplam Borç / Öz Sermaye oranları için 0,5, KVYK / Toplam Aktif oranı için 0,3 olarak alınmış ve standartlaştırılırken Eşitlik 6 kullanılmıştır. Ardından her sütunun en büyük değerlerinden Referans Serisi oluşturulmuştur. Standartlaştırılmış karar matrisi ve referans değerler Tablo 9'da verilmiştir: 
Tablo 9: Bilişim ve Teknoloji Alanında Faaliyet Gösteren İşletmelerin 2005-2011 Yılları Arası Standartlaştırılmış Karar Matrisi ve Referans Değerleri

\begin{tabular}{|l|c|c|c|c|c|c|c|c|c|c|c|c|}
\hline \multirow{2}{*}{ Şirket } & \multicolumn{2}{|c|}{ Likidite Oranları } & \multicolumn{3}{|c|}{ Mali Yapı Oranları } & \multicolumn{3}{c|}{ Karlılı Oranları } & \multicolumn{3}{c|}{ Faaliyet Oranları } \\
\cline { 2 - 14 } & LO1 & LO2 & LO3 & MYO1 & MYO2 & MYO3 & KO1 & KO2 & KO3 & FO1 & FO2 & FO3 \\
\hline ALCTL & 0.00 & 0.02 & 0.01 & 0.27 & 0.00 & 0.05 & 0.05 & 0.35 & 0.58 & 0.00 & 0.42 & 0.79 \\
\hline ANELT & 0.07 & 0.11 & 0.13 & 0.96 & 0.45 & 0.94 & 0.00 & 0.00 & 0.00 & 0.10 & 0.06 & 0.77 \\
\hline ARENA & 0.00 & 0.00 & 0.00 & 0.46 & 0.40 & 0.08 & 0.06 & 1.00 & 1.00 & 0.72 & 0.89 & 0.99 \\
\hline ASELS & 0.08 & 0.05 & 0.06 & 0.55 & 0.55 & 0.87 & 0.54 & 0.89 & 0.84 & 0.56 & 0.05 & 0.67 \\
\hline DGATE & 0.01 & 0.01 & 0.00 & 0.41 & 0.21 & 0.00 & 0.03 & 0.52 & 0.82 & 0.78 & 1.00 & 1.00 \\
\hline ESCOM & 0.01 & 0.01 & 0.00 & 0.73 & 0.90 & 0.80 & 0.01 & 0.10 & 0.34 & 0.06 & 0.10 & 0.00 \\
\hline INDES & 0.00 & 0.00 & 0.00 & 0.39 & 0.32 & 0.04 & 0.04 & 0.52 & 0.73 & 0.37 & 0.65 & 0.91 \\
\hline LINK & 0.39 & 0.55 & 0.49 & 0.00 & 0.90 & 0.50 & 1.00 & 0.59 & 0.40 & 0.01 & 0.00 & 0.68 \\
\hline LOGO & 0.15 & 0.24 & 0.14 & 0.17 & 0.92 & 0.60 & 0.28 & 0.95 & 0.50 & 0.14 & 0.01 & 0.69 \\
\hline NETAS & 0.07 & 0.11 & 0.11 & 0.56 & 1.00 & 0.94 & 0.31 & 0.77 & 0.51 & 0.05 & 0.02 & 0.68 \\
\hline PKART & 1.00 & 1.00 & 1.00 & 0.08 & 0.91 & 0.43 & 0.01 & 0.19 & 0.35 & 1.00 & 0.05 & 0.69 \\
\hline $\begin{array}{l}\text { Referans } \\
\text { Seri }\end{array}$ & 1.00 & 1.00 & 1.00 & 0.96 & 1.00 & 0.94 & 1.00 & 1.00 & 1.00 & 1.00 & 1.00 & 1.00 \\
\hline
\end{tabular}

Tablo 10' dan ise referans serisindeki değerlerin, standartlaştırılmış karar matrisindeki değerlerinden farkları alınarak elde edilen fark matrisi görülebilmektedir:

Tablo 10: Bilişim ve Teknoloji Alanında Faaliyet Gösteren İşletmelerin 2005-2011 Y1lları Arası Finansal Oranlarının Fark Matrisi

\begin{tabular}{|c|c|c|c|c|c|c|c|c|c|c|c|c|}
\hline \multirow{2}{*}{ Şirket } & \multicolumn{3}{|c|}{ Likidite Oranları } & \multicolumn{3}{c|}{ Mali Yapı Oranları } & \multicolumn{2}{c|}{ Karlılı Oranları } & \multicolumn{3}{|c|}{ Faaliyet Oranları } \\
\cline { 2 - 14 } & LO1 & LO2 & LO3 & MYO1 & MYO2 & MYO3 & KO1 & KO2 & KO3 & FO1 & FO2 & FO3 \\
\hline ALCTL & 1.00 & 0.98 & 0.99 & 0.68 & 1.00 & 0.89 & 0.95 & 0.65 & 0.42 & 1.00 & 0.58 & 0.21 \\
\hline ANELT & 0.93 & 0.89 & 0.87 & 0.00 & 0.55 & 0.00 & 1.00 & 1.00 & 1.00 & 0.90 & 0.94 & 0.23 \\
\hline ARENA & 1.00 & 1.00 & 1.00 & 0.49 & 0.60 & 0.86 & 0.94 & 0.00 & 0.00 & 0.28 & 0.11 & 0.01 \\
\hline ASELS & 0.92 & 0.95 & 0.94 & 0.40 & 0.45 & 0.07 & 0.46 & 0.11 & 0.16 & 0.44 & 0.95 & 0.33 \\
\hline DGATE & 0.99 & 0.99 & 1.00 & 0.55 & 0.79 & 0.94 & 0.97 & 0.48 & 0.18 & 0.22 & 0.00 & 0.00 \\
\hline ESCOM & 0.99 & 0.99 & 1.00 & 0.22 & 0.10 & 0.14 & 0.99 & 0.90 & 0.66 & 0.94 & 0.90 & 1.00 \\
\hline INDES & 1.00 & 1.00 & 1.00 & 0.57 & 0.68 & 0.90 & 0.96 & 0.48 & 0.27 & 0.63 & 0.35 & 0.09 \\
\hline LINK & 0.61 & 0.45 & 0.51 & 0.96 & 0.10 & 0.44 & 0.00 & 0.41 & 0.60 & 0.99 & 1.00 & 0.32 \\
\hline LOGO & 0.85 & 0.76 & 0.86 & 0.78 & 0.07 & 0.34 & 0.72 & 0.05 & 0.50 & 0.86 & 0.99 & 0.31 \\
\hline NETAS & 0.93 & 0.89 & 0.89 & 0.40 & 0.00 & 0.00 & 0.69 & 0.23 & 0.49 & 0.95 & 0.98 & 0.32 \\
\hline PKART & 0.00 & 0.00 & 0.00 & 0.87 & 0.09 & 0.51 & 0.99 & 0.81 & 0.65 & 0.00 & 0.95 & 0.31 \\
\hline
\end{tabular}


Gri İlişkisel Katsayılar eşitlik 11 kullanılarak hesaplanmıştır, hesaplamalarda $=0,5$ olarak alınmıştır, katsayılar Tablo 11'de verilmiştir:

Tablo 11: Bilişim ve Teknoloji Alanında Faaliyet Gösteren İşletmelerin 2005-2011

Yılları Arası Finansal Oranlarının Gri İlişkisel Katsayıları

\begin{tabular}{|l|c|c|c|c|c|c|c|c|c|c|c|c|}
\hline \multirow{2}{*}{ Şirket } & \multicolumn{3}{|c|}{ Likidite Oranlar } & \multicolumn{3}{c|}{ Mali Yapı Oranları } & \multicolumn{2}{c|}{ Karlılı Oranları } & \multicolumn{3}{c|}{ Faaliyet Oranları } \\
\cline { 2 - 13 } & LO1 & LO2 & LO3 & MYO1 & MYO2 & MYO3 & KO1 & KO2 & KO3 & FO1 & FO2 & FO3 \\
\hline ALCTL & 0.33 & 0.34 & 0.34 & 0.42 & 0.33 & 0.36 & 0.34 & 0.44 & 0.54 & 0.33 & 0.46 & 0.71 \\
\hline ANELT & 0.35 & 0.36 & 0.36 & 1.00 & 0.48 & 1.00 & 0.33 & 0.33 & 0.33 & 0.36 & 0.35 & 0.68 \\
\hline ARENA & 0.33 & 0.33 & 0.33 & 0.50 & 0.46 & 0.37 & 0.35 & 1.00 & 1.00 & 0.64 & 0.81 & 0.98 \\
\hline ASELS & 0.35 & 0.34 & 0.35 & 0.55 & 0.53 & 0.87 & 0.52 & 0.82 & 0.75 & 0.53 & 0.35 & 0.60 \\
\hline DGATE & 0.33 & 0.34 & 0.33 & 0.48 & 0.39 & 0.35 & 0.34 & 0.51 & 0.74 & 0.70 & 1.00 & 1.00 \\
\hline ESCOM & 0.34 & 0.34 & 0.33 & 0.69 & 0.84 & 0.79 & 0.34 & 0.36 & 0.43 & 0.35 & 0.36 & 0.33 \\
\hline INDES & 0.33 & 0.33 & 0.33 & 0.47 & 0.42 & 0.36 & 0.34 & 0.51 & 0.65 & 0.44 & 0.59 & 0.85 \\
\hline LINK & 0.45 & 0.52 & 0.49 & 0.34 & 0.83 & 0.53 & 1.00 & 0.55 & 0.45 & 0.33 & 0.33 & 0.61 \\
\hline LOGO & 0.37 & 0.40 & 0.37 & 0.39 & 0.87 & 0.60 & 0.41 & 0.90 & 0.50 & 0.37 & 0.34 & 0.62 \\
\hline NETAS & 0.35 & 0.36 & 0.36 & 0.56 & 1.00 & 1.00 & 0.42 & 0.69 & 0.51 & 0.35 & 0.34 & 0.61 \\
\hline PKART & 1.00 & 1.00 & 1.00 & 0.36 & 0.85 & 0.50 & 0.34 & 0.38 & 0.44 & 1.00 & 0.35 & 0.61 \\
\hline
\end{tabular}

Eşitlik 12 kullanılarak AHP'den elde edilen ağırlıklar ile gri ilişkisel katsayı matrisi çarpılmış ve şirketlerin gri ilişki dereceleri hesaplanmıştır. Gri ilişski dereceleri büyükten küçüğe sıralanarak şirketlerin performansları elde edilmiştir, sonuçlar Tablo 12'de verilmiştir:

Tablo 12: Bilişim ve Teknoloji Alanında Faaliyet Gösteren İşletmelerin 2005-2011

Yılları Arası Finansal Oranlarının Gri İlişkisel Dereceleri ve Sıralamaları

\begin{tabular}{|l|c|c|c|c|c|c|c|c|c|c|c|}
\hline & ALCTL & ANELT & ARENA & ASELS & DGATE & ESCOM & INDES & LINK & LOGO & NETAS & PKART \\
\hline GiD (Ort) & 0.41 & 0.43 & 0.57 & 0.55 & 0.51 & 0.43 & 0.46 & 0.66 & 0.51 & 0.52 & 0.60 \\
\hline Sira No. & 11 & 9 & 3 & 4 & 7 & 10 & 8 & 1 & 6 & 5 & 2 \\
\hline
\end{tabular}

Tablo 12'den görüldüğü gibi 2005-2011 yılları arasında performansı en iyi olan işletme 0.66 ilişki derecesi ile LINK' dir, bunu 0.60 ilişki derecesiyle PKART ve 0.57 ilişki derecesiyle ARENA takip etmektedir. Performansı en düşük olan işletmeler ise, dokuzuncu sırada 0.43 ilişki derecesiyle ANELT, onuncu sırada 0.43 ilişki derecesiyle ESCOM ve on birinci sırada 0.41 ilişki derecisiyle ALCTL işletmesi yer almıştır.

\section{SONUÇ}

Ülke ekonomilerinin alt birimleri olarak görülen sektörlerin performanslarının incelenmesi ve değerlendirilmesi makroekonomik açıdan ülke ekonomileri, mikro ekonomik 
açıdan ise işletme sahipleri ve yöneticileri için büyük öneme sahiptir. Makroekonomik açıdan ilgili sektörün, ülke ekonomisine sağlamış olduğu katma değer ve durumu değerlendirilebilmekte, mikro ekonomik açıdan işletme sahip ve yöneticileri sektör içerisinde işletmelerin performanslarını görebilmekte ve bu doğrultuda işletmeler açısından daha stratejik kararlar alabilme olanağına ulaşabilmektedirler. Yapılan çalışmada bilişim ve teknoloji sektörünün performansı AHP ve GİA yöntemleri kullanılarak ortaya konmuştur. İlk olarak İMKB ve KAP'dan işletme bilanço ve gelir tablolarından elde edilen oranlar AHP yöntemi kullanılarak ağırlığı en fazla olan kriter elde edilmeye çalışılmıştır. Ayrıca kriterlerin ikişerli karşılaştırmalarının tutarlı olması sağlanmış ve mali yapı oranlarında ideal değer kullanımı GİA ile sağlandığından çalışmada kullanılan yöntemlerin diğer çok kriterli karar verme yöntemlerinden daha üstün olduğu ve kullanılan yöntemlerin uygun yöntemler olduğu ve olumlu sonuçlar verdikleri söylenebilir. AHP yöntemi ile ağırlığı en fazla olan kriterin karlılık oranları olduğu görülmüş ve edilen bulgular doğrultusunda GİA yöntemi uygulanarak sektördeki işletmelerin performanslarına yönelik her bir işletme için 2005-2011 yılları itibariyle gri ilişkisel dereceler hesaplanmıştır. Sektördeki performansı en yüksek olan LINK işletmesinin gri ilişkisel derecesi 0.66 olurken, en düşük performansa sahip ALCTL işletmesinin gri ilişkisel derecesi 0.41 olmuştur.

En iyi performans sergileyen LINK işletmesinin çalışmanın kapsadığı dönemler içinde likidite oranları açısından kabul edilen düzeyde olduğu, borçlanma politikasının doğru olarak kullanıldığı ve sektörde faaliyet gösteren diğer işletmelere göre karlı olarak faaliyetlerini sürdürdüğü sonucuna ulaşılmıştır. En fazla ağırlığa sahip kriter olarak belirlenen karlılık oranları dikkate alındığında ise LINK işletmesinin karlılık oranlarının diğer işletmelere göre yüksek seviyelerde seyrettiği, düşük performans sergileyen işletmelerin karlılık oranlarının ise genel olarak istenen seviyelerde olmadığı görülmektedir. Dolayısıyla bu çalışmada ele alınan örneklem için dikkate alınması gereken kriter olarak karlılık oranlarının belirlenmesinin isabetli bir karar olduğunu ve uygulanan yöntemin söz konusu işletmelerin finansal performanslarını sıralamada yeterli geldiğini söylemek mümkündür.

$\mathrm{Bu}$ çalışmanın sonucunda elde edilen bulgular doğrultusunda finansal performansı düşük ve orta seviyede olan işletmelere öneri olarak; finansman ve satış politikalarını yeniden gözden geçirip, rakip işletmelerin durumlarını iyi değerlendirerek bu noktada çözüme yönelik stratejiler geliştirip performanslarını sektör ortalamasının üzerine çekmeleri gerekmektedir. 


\section{KAYNAKLAR}

Akın, H. Bahadır (2005), Yeni Ekonomi (Strateji, Rekabet ve Küreselleşme), Güncellenmiş 2. Baskı, Çizgi Kitabevi, Konya.

Arifin, A. Zainul (2011). "The Analytical Process (AHP) Method For Stocks Rank", Cambridge Business \& Economics Conference, 27- 28 Haziran 2011, pp. 1- 26.

Aydın, İsmail (2012). “Bilişim Sektörü ve Türkiye'nin Sektördeki Potansiyeli”, International Journal of New Trends in Arts, Sports \& Science Education, Vol. 1, No. 1, pp. 180-200.

Barbarosoğlu, Gülay- Pinhas, David (1995). "Capital Rationing In The Public Sector Using The Analytic Hierarchy Process", The Engineering Economist, Vol. 40, No. 14, pp. 315-326.

Bayyurt, Nizamettin. (2007). “İşletmelerde Performans Değerlendirmenin Önemi ve Performans Göstergeleri Arasındaki İlişkiler”, Sosyal Siyaset Konferansları Dergisi, Say1 53, ss. 577-590.

Brigham, F. Eugene-Houston, F. Joel (1996). Fundamentals of Financial Management, The Concise Edition, The Dryden Press Harcourt Brace College Publishers, United States of America.

Ceylan, Cengiz-Çağlar, Ünal (2011). "Küreselleşmenin Sektörel Etkileri: Araştırma Projesi”, İstanbul Ticaret Odası Yayınları Küresel Ekonomik Araştırmalar, Yayın No: 2010-98, İstanbul.

Deng, Julong (1989). "Introduction to Grey System Theory", The Journal of Grey System, Vol.1, No. 1, pp. 1-24.

DPT. (2001) "Sekizinci Beş Yıllık Kalkınma Planı, Bilişim Teknolojileri ve Politikaları Özel İhtisas Komisyonu Raporu”, DPT: 2560-ÖIK: 576, Ankara.

Erdoğan, Muammer (2011), Finansal Yönetim, 2. Bask1, Aktif Yayınevi, Erzurum.

Hamzaçebi, Coşkun-Pekkaya, Mehmet (2011). "Determining of Stock Investments with Grey Relational Analysis, Expert Systems with Applications, Vol. 38, No. 8, pp. 9186- 9195.

Ilgaz, Barış “Oran Analizi”. ss. 1-28. http://www.bilgaz.net/dosyalar/OranAnalizi.pdf. (10.09.2013).

İç, Yusuf Tansel-Yurdakul, Mustafa (2000). “Analitik Hiyerarşi Süreci (AHP) Yöntemini Kullanan Bir Kredi Değerlendirme Sistemi”, Gazi Üniversitesi Mühendislik Mimarlık Fakültesi Dergisi, Cilt: 15, Say1: 1, ss. 1-14.

Karğın, Mahmut (2010). "Bulanık Analitik Hiyerarşi Süreci ve İdeal Çözüme Yakınlığa Göre Sıralama Yapma Yöntemleri ve Tekstil Sektöründe Finansal Performans Ölçümü”, Celal Bayar Üniversitesi Sosyal Bilimler Dergisi, Cilt: 8, Sayı: 1, ss. 195-216.

Kulalı, İhsan-Bilir, Hakan (2010). Bilgi ve İletişim (Telekomünikasyon) Sektöründeki Gelişmeler ve Eğilimler, TOBB Yayınları, TOBB Yayın No: 2010-102. 
Kung, Chaang Yung-Wen, Kun Li (2007). “Applying Grey Relational Analysis and Grey Decision-Making to Evaluate the Relationship Between Company Attributes and Its Financial Performance- A Case Study of Venture Capital Enterprises in Taiwan”, Desicion Support Systems, Vol. 43, No. 3, pp. 842-852.

Lee, Heeseok-Kwak, Wikil-Han, Ingoo (1995). "Developing A Business Performance Evaluation System: An Analytical Hierarchical Model", The Engineering Economist, Vol. 40, No. 4, pp. 343- 357.

Lin, Shu Ling-Wu, Shun Jyh (2011). "Is Grey Relational Analysis Superior to the Conventional Techniques in Predicting Financial Crisis?", Expert Systems with Applications, Vol. 38, No. 5, pp. 5119- 5124.

Okka, Osman (2011). "İşletme Finansmanı”, 5. Baskı, Nobel Yayın Dağıtım, Ankara.

Önder, Mehmet (2008). “Geleceğin Bacasız Sanayisi; Yazılım Sektörü”, Çerçeve Dergisi Geleceğin Dünyası Emek Toplumundan Bilgi Toplumuna, Cilt: 16, Say1: 47, ss. 162163.

Özdemir, Ali İhsan-Deste, Mustafa (2009). "Gri İlişkisel Analiz ile Çok Kriterli Tedarikçi Seçimi: Otomotiv Sektöründe Bir Uygulama”, İstanbul Üniversitesi İşletme Fakültesi Dergisi, Cilt: 38, Say1: 2, ss. 147-156.

Peker, İskender-Baki, Birdoğan (2011). “Gri İlişkisel Analiz Yöntemiyle Türk Sigortacıllk Sektöründe Performans Ölçümü”, Uluslararası İktisadi ve İdari İncelemeler Dergisi, Cilt: 3, Say1: 7, ss. 1-17.

Perçin, Selçuk-Karakaya, Aykut (2012). "Bulanık Karar Verme Yöntemleriyle Türkiye’de Bilişim Teknolojisi Firmalarının Finansal Performanslarının Değerlendirilmesi”, Marmara University Journal of the Faculty of Economic \& Administrative Sciences, Vol. 33, No. 2, pp. 241-266.

Rangone, Andrea (1996). “An Analytical Hierarchy Process Framework For Comparing The Overall Performance of Manufacturing Departments", International Journal of Operations \&Production Management, Vol. 16, No. 8, pp. 104- 119.

Soner, Selin- Önüt, Semih. (2006). "Multi-Criteria Supplier Selection: An Electre - Ahp Application". Journal of Engineering and Natural Sciences Sigma, Cilt: 4, ss. 110-120. Tekin, Mahmut-Zerenler, Muammer (2005) “ İş Dünyası İçin Krizi Yönetebilmenin Sırları", 1. Baskı, Çizgi Kitapevi, Konya.

Türkmen, Sibel Yılmaz-Çağıl, Gülcan (2012) “İMKB’ye Kote Bilişim Sektörü Şirketlerinin Finansal Performanslarının TOPSIS Yöntemi ile Değerlendirilmesi”, Maliye Finans Yazıları, Cilt: 26, Say1: 95, ss. 59-78.

Türko, Metin (1999). "Finansal Yönetim”, 1. Baskı, Alfa Yayınları, İstanbul.

Ulucan, Aydın (2007). "Yöneylem Araştırması, İşletmecilik Uygulamalı Bilgisayar Destekli Modelleme", Siyasal Kitabevi, Ankara. 
Usta, Öcal (2008). “İşletme Finansı ve Finansal Yönetim”, 3. Baskı, Detay Yayıncılık, Ankara.

Üstünışık, Naime Zerrin (2007). "Türkiye'deki İller ve Bölgeler Bazında Sosyo-Ekonomik Gelişmişlik Sıralaması Araştırması: Gri İlişkisel Analiz Yöntemi ve Uygulaması”, Yüksek Lisans Tezi, Gazi Üniversitesi Fen Bilimleri Enstitüsü.

Wu, Cheng Ru- Lin, Chin Tsai- Tsai Pei Hsuan (2010). "Evaluating Business Performance of Wealth Management Banks”, European Journal of Operational Research, Vol. 207, No. 2, pp. 971- 979.

YASED (2012), “2023 Hedefleri Yokunda Bilgi ve İletişim Teknolojileri”, Uluslararası Yatırımcılar Derneği Raporu.

Yüksel, İhsan-Akın, Adnan (2006). “Analitik Hiyerarşi Proses Yöntemiyle İşletmelerde Strateji Belirleme”, Doğuş Üniversitesi Dergisi, Cilt: 7, Sayı: 2, ss. 254-268.

Zhai, Lina Yin-Khoo, Li Pheng-Zhong, Zhao Wei (2009). "Design Concept Evaluation in Product Development Using Rough Sets and Grey Relational Analysis", Expert Systems with Applications, No. 36, pp. 7072-7079. 